\title{
Por uma nova leitura de Michelet no Brasil
}

\author{
TEIXEIRA, Maria Juliana Gambogi. A Profetisa e o Historiador: sobre A \\ Feiticeira de Jules Michelet. Belo Horizonte: Editora UFMG, 2017. 312 p.
}

Renato Fagundes Pereira ${ }^{1}$

No século XIX, algumas obras de Jules Michelet foram trazidas ao Brasil, isso se deve, em partes, ao sucesso de L'Oiseau (1857) em Paris, (onde estimava-se a venda de trinta e três mil unidades), embora a recepção de suas ideias tenha ocorrido principalmente na segunda metade do século $X X$, com as primeiras traduções das obras historiográficas e teóricas do movimento dos Annales (Lucien Febvre nunca negou o legado micheletiano em suas análises). A partir da década de 1970, as ideias de Michelet chegam ou por aqueles que discutiam a história e a metodologia dos Annales ou por aqueles que começavam a refletir sobre a crise dos paradigmas na historiografia -A presença de Jules Michelet é marcante nos livros de Peter Burke e Dosse sobre os Annales, por exemplo, e nos argumentos de Paul Veyne, Michel de Certeau, Jacques Rancierè e Hayden White sobre as ficcionalidades da história.

Muitos estudos foram publicados no Brasil, os quais assinalam a importância de Jules Michelet como precursor dos Annales, da história das mulheres, do povo e da cultura, mas, raros são aqueles que se esforçaram em compreender o historiador no movimento do seu próprio pensamento, no élan-criador do conhecimento histórico e na historicidade do próprio autor. Nesse sentido, não são exageros as palavras Jean-Michel Rey sobre a modéstia do subtítulo, A feiticeira de Jules Michelet, no recém-lançado livro A profetisa e o historiador de Maria Juliana Gambogi Teixeira.

A professora da UFMG retoma sua tese doze anos depois de sua defesa, são quase três décadas dedicadas a finco à pesquisa das ideias micheletianas, e nos proporciona uma leitura singular, inaudita, principalmente, entre nós, brasileiros, acostumados com a recepção do autor da L'Histoire de France, pelos herdeiros dos Annales. Essa distinção se assenta pelo vínculo de Gambogi Teixeira com o grupo formado por Paul Viallaneix e Paule Petitier. Esses dois especialistas na obra micheletiana realizaram nas últimas décadas um

1 Professor do Curso de História da Universidade Estadual de Goiás - UEG. -E-mail: renatofagundesp@gmail.com 
trabalho árduo de muita riqueza, descobrindo e publicando textos inéditos de Michelet, organizando coletâneas, bibliotecas e seminários - podemos destacar o seminário Michelet hors fronteires e a bibliothèque Jacques Seebacher, ambos com a coordenação da professora da Universidade Diderot, Paule Petitier.

O livro é dividido em três partes com dois capítulos cada um. A parte um, O Tenebroso Mar de La Sorcière é preciosa para compreender a trama que atravessa todo o livro: $A$ Feiticeira, obra publicada por Michelet, em 1862. Enganar-se-ia quem imaginasse encontrar nessas páginas apenas a história de um livro. Trata-se de um esforço mais profundo, na tentativa de constituir no interior da obra monumental de Jules Michelet o caminho da feitiçaria como objeto, suas inflexões e seus delineamentos, durante mais de meio século de produção do historiador. A análise do próprio texto, A Feiticeira, se apresenta, principalmente, no capítulo dois, no entanto, ela não acontece fora de um solo, como gostava de afirmar o próprio Michelet, e sim dentro de um plano de imanência micheletiano, que só é possível por uma conhecedora dos arquivos e das ideias do século XIX.

A parte dois do livro, História ao Pé da Letra, representa uma contribuição das mais notáveis: a história da historiografia e a teoria da história. Gostaríamos de insistir na novidade dessa análise no Brasil e em textos em língua portuguesa. A autora retoma o vínculo entre Michelet e Vico, explorado desde o século XIX, para romper com ele e demonstrar no contexto das ideias o débito viconiano, enfatizando as rupturas e as criações micheletianas. A questão da lenda e da cultura popular, familiar ao romantismo, emerge no capítulo final dessa parte. Particularmente, os dois capítulos que fazem parte desse recorte são os quais a pesquisadora mais me surpreende pelo gênio de articulação e uma consistência de domínio teórico, cuja finalidade é estabelecer a relação entre o lendário, a história e o ficcional em Jules Michelet.

Na última parte do livro, Verso e Avesso da Narrativa, Gambogi conduz sua reflexão da obra micheletiana no movimento de mão-dupla: da constituição do seu pensamento, no esforço intelectual de escrever história, concentra-se na Feiticeira e no fenômeno da feitiçaria e no interior das questões pessoais, políticas e sociais enfrentadas pelo autor. Não por acaso, a tese da autora sobre La Sorcière passa pela associação de Jules Michelet com a Revolução de 1848, na França:

\footnotetext{
Projetando tal hipótese sobre o cenário aberto por 1848, parece-nos possível pensar que, menos do que um interesse circunscrito em catalogar e diagnosticar o destino pontual dos movimentos revoltosos, o pensamento de Michelet tenha se voltado para, em La Sorcière para o que sempre fora seu centro: a condição de inteligibilidade da história moderna. Já há muito, o historiador fincara essa condição num campo de entendimento em que se conflitam dois princípios diversos, porém imbricados em seu destino: o princípio da Revolução e o princípio do cristianismo (p. 203).
} 
O livro de Maria Juliana Gambogi Teixeira se dedica a pensar a construção do conhecimento histórico em Jules Michelet e sua íntima relação com os desafios enfrentados pelo autor no século XIX, período em que o campo historiográfico ainda estava em construção. É nesse aspecto que a finesse micheletiana brota, quais suas estratégias? Como ele relaciona a história com a cultura popular e os acontecimentos políticos? Qual a fronteira entre história e literatura? Como podemos pensar a relação entre Vico e Michelet? É possível separar a política da escrita histórica no pensamento micheletiano? São esses e outros questionamentos que Teixeira responde ao apropriar-se de um sólido arquivo. Aqueles interessados na história da historiografia e teoria da história verão nesse texto uma fonte inspiradora para uma análise criativa que cativa o leitor pelos desafios que ela mesma propõe.

Recebido em 27/02/2018

Aprovado em 03/10/2018 